\title{
Dancing in the 'contact zone'
}

\section{Monica Wulff, University of Technology Sydney}

In October 2002 I performed and exhibited Troppo Obscura: A Peepshow of Historical Perversity at the Performance Space as part of the multicultural Arts festival, Carnivale, in Sydney, Australia. Troppo Obscura was a multimedia installation that explored some aspects of the complex relationships between the West and Asia. The work looked at a large range of possibilities, from the colonial gaze through to personal relationships forged through artistic endeavour. This paper focuses on one such personal relationship addressed in the installation, namely that between traditional master mask dancer Ibu Sawitri from Cirebon on the West coast of Java, Indonesia, and myself, a Sydney based contemporary dancer and performance artist. Between 1992 and 1999, the year Ibu Sawitri passed away, I spent many long-term visits learning dance and living in Ibu Sawitri's house in Losari.

Troppo Obscura was an artistic collaboration between Sydney-based director and performer Deborah Pollard, video artist Sam James, sound artist Gail Priest, Indonesian-based sculptor Hedi Heriyanto, and myself as concept devisor and performer. The installation was exhibited in one of the ground floor Performance space galleries and consisted of five larger-than-life bellows camera sculptures made by Hedi Heriyanto. Two of the cameras housed live performers; another two contained video players projecting film loops of old archival material. This film material, which I researched and copied from the Dutch National film archives NAA, was shot by the Dutch during the Indonesian colonial period from as early as 1912. Live video footage 
of Ibu Sawitri presented in one of the camera boxes was shot by cinematographer Peter Panoa during visits to Ibu Sawitri in Cirebon between 1996-1999. The far end wall of the gallery hosted a large video-loop projection of myself dressed in colonial garb performing a series of mask dances. This footage was made to look like old black and white archival film footage and looped throughout the duration of the installation. Reminiscent of the Victorian Peepshow the camera boxes were provided with small peeping holes through which audience members could view the contents of each camera box. Headsets were provided which contained accompanying soundtracks by Gail Priest. Each camera box addressed a particular aspect of the East-West relationship ranging from colonial times to the present.

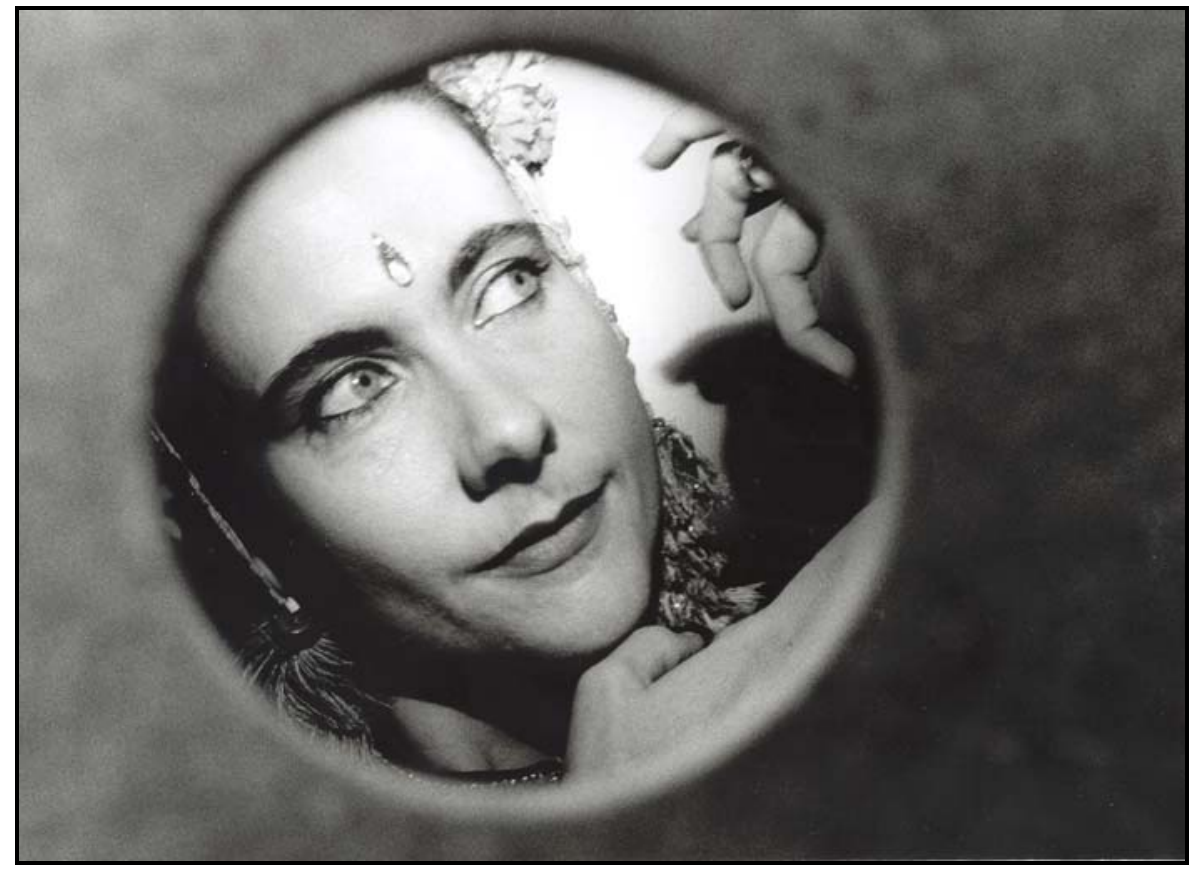

Troppo Obscura, October 2002, Dancing in the Box

I envisage this essay as a two part series, the composite paper of which is titled $I b u$ Sawitri and the A/Occidental Oriental. ${ }^{1}$ This paper is about Ibu Sawitri’s family and dance background and how she, the younger generation of dancers, the dance context, and the dance itself, have been transformed over time as a result of rapidly changing socio-historical conditions. In the second half of this essay I move the discussion to the

\footnotetext{
${ }^{1}$ Also published in PORTAL in this special issue on Women in Asia.
} 
broader issues of cross-cultural encounters in what Pratt terms the 'contact zone' (1992).

This involves looking at dance as an embodied practice and its function in the 'contact zone', as well as dealing with Spivak's debates about the subaltern voice in reference to my telling of Ibu Sawitri's story, both in the installation and in text. A closer analysis of the dynamics of my dance with Ibu Sawitri in 'contact zone’ is addressed here.

\section{Commencing the Dance}

After staring at the computer screen long enough I feel myself being hypnotically drawn into its white surface. I am surrounded by thick fog, floating in a white cloud, hanging suspended in a moment of beginning. Looking at all this empty white that is ever so slowly filling up with little black letters intercepted by short spaces in neat rows, like ants on a mission, I am reminded of the time I danced in the snow. I performed a series of dance movements from Panji Sutrawinangun, the first mask dance that Ibu Sawitri, my Cirebonese mask dancing teacher and dear friend taught me. ${ }^{2}$ I danced silently in an open, snow-covered field in Groningen, the North of Holland, to an audience composed of my partner Rogier (who had agreed to film the event) and the occasional bemused passer-by. The panji mask is small and white with a sharp nose and thin upturned red lips. I was wearing a long red overcoat that together with the mask made a striking contrast with the white snow-covered landscape so reminiscent of this luminous white screen. The snow and haze produced an eerie silence that was interrupted only by the sound of snow crunching under my winter boots and the sound of my foggy breath filtering through the small nostril holes in the mask.

At the time I was interested to see how the white of the mask, the red of the coat, and the movements of a dance so specific to Indonesia and a tropical atmosphere, would appear on a western-clad body in a quintessentially European winter setting. I was interested in the paradox and incongruity of this scene that cuts across colonial history and serves to deconstruct the box into which traditional Indonesian dance, Indonesian woman, and western woman performing Asian dance are neatly locked. That was the

\footnotetext{
${ }^{2}$ Ibu literally means mother but when placed in front of a person's name indicates the polite form of address to an older woman. To refer to an older woman by her first name without using the honorific title $I b u$ would be regarded as demeaning.
} 
concept. Perceptually, however, my body experienced a very different story. As I was dancing I thought of Ibu and the time I spent with her before her death a year prior to the dance in the snow. I was filled with a great sadness and sense of loss-not only for Ibu Sawitri as it transpired, but for my own grandmother, Nan, who had died in Australia while I was in Europe ten years earlier and whose death I had never really given myself the time or permission to mourn.

During the last few months I spent with Ibu Sawitri she told me that there were still many places in the world that she would like to see. For years she had asked me to bring her a long warm overcoat from Australia. Initially I found her request unusual, not least because Indonesia is a tropical country and the countryside on the North coast of Cirebon is particularly hot. I assumed she wanted the coat in case she and her mask dancing troupe were ever asked to perform overseas again, like they had in November 1993 when they had been sponsored by UNICEF to perform in New York, or maybe to wear on visits to Bandung or Bogor, which are located in the hills and therefore have cooler climates. We had often talked about Ibu visiting Australia, the funding for which I was at that time still trying to secure. It was only on my last visit to Cirebon that I finally managed to fulfil Ibu Sawitri’s request by bringing her a three-quarter-length Eucalyptus-green trench coat.

Looking back I am not surprised that it was almost identical to a coat Nan used to have. Ibu wore the coat over her kebaya and batik sarong on what she considered cold nights during the rainy season but, sadly, never had the opportunity to wear it overseas. She died two months after my last visit to the village in 1999. I remember thinking as I was wearing my red vinyl trench coat, dancing panji in the snow, that perhaps somehow through my body and the mask Ibu was visiting another place in the world after all. Nan had been in Germany with us for the first year in 1973. Never having been to Europe before she had a hard time with the Glatteis (frozen slippery ground) during that first winter. She slipped once and broke her false teeth, her 'clackers' as she called them. Lying on the slippery ground unable to get up she had fumbled in her bag for her dictionary to look up the word for help. Hilfe! Her name being Gertrude, she was 
referred to as Glatteis Gerty from that day forward. If nothing else, by dancing in the snow I was paying tribute to the memory of two important, influential and loved women in my life.

Meanwhile all this talk about snow is no doubt influenced by the fact that it is winter in Sydney and a particularly cold day today. As I sit and type I can feel my cheeks, nose and fingers tingling from the adjustment to the evenly air-conditioned, windowless basement that houses my 'workstation'. Around me the neon lights hum and illuminate the space in white light, which bounces crisply off the maze of white desks and blue partitions. My partition in defiance of office anonymity is covered with an eclectic collection of postcards, photos and posters of Indonesian dancers, past performances, and a close-up picture of Ibu Sawitri taken during my last visit. I look closely at the photograph of her wrinkled light brown face, her small rounded nose, her mouth in that familiar half smile and the wisps of grey and black hair that hang loosely around her face. Even in this close-up, traces of her old beauty are still visible. Those traces surprised me the first time I met Ibu Sawitri at her home in Losari. Thin, leathery skinned, toothless, wearing her usual attire of kain batik, loose kebaya and worn plastic slippers, she nevertheless emanated magnetic presence, charm and beauty. She often had a cheeky twinkle in her eyes and was as genit and funny as the best of them,

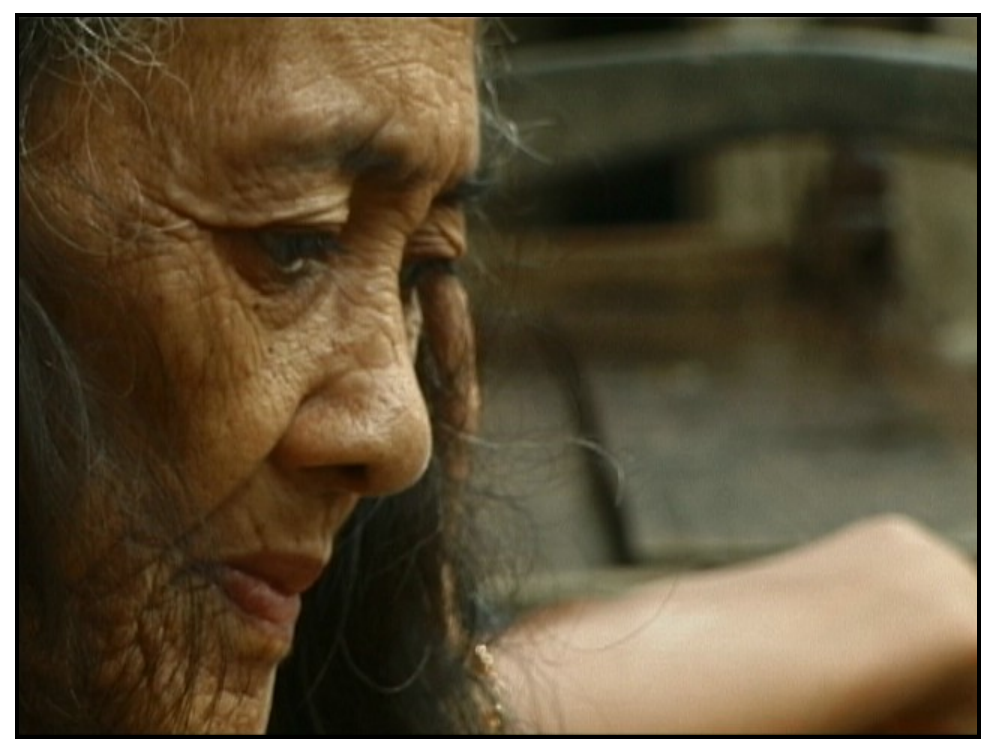

Ibu Sawitri, Losari/Cirebon, 1999 
especially when in the company of men of rank and importance. The other noticeable aspect of her physicality was her straight back and her quick energetic movements, which made her appear tall, proud and younger than her wrinkled, thin exterior would otherwise suggest.

We spent that first afternoon chatting in the front guest room, me drinking kopi tubruk with copious amounts of sugar and Ibu smoking fat unfiltered Gudang Garam cigarettes. The guest room of the family house was an odd mix of old and new. The back and side walls separating the guest room from the interior of the house consisted of deep-brown teak planks from the bottom to the middle of the wall, but the middle to the top consisted of typical Javanese village-style, whitewashed, thatched bamboo. These walls were sparsely hung with a handful of old plastic framed photographs of family, performances and awards. The front of the house was a modern brick wall

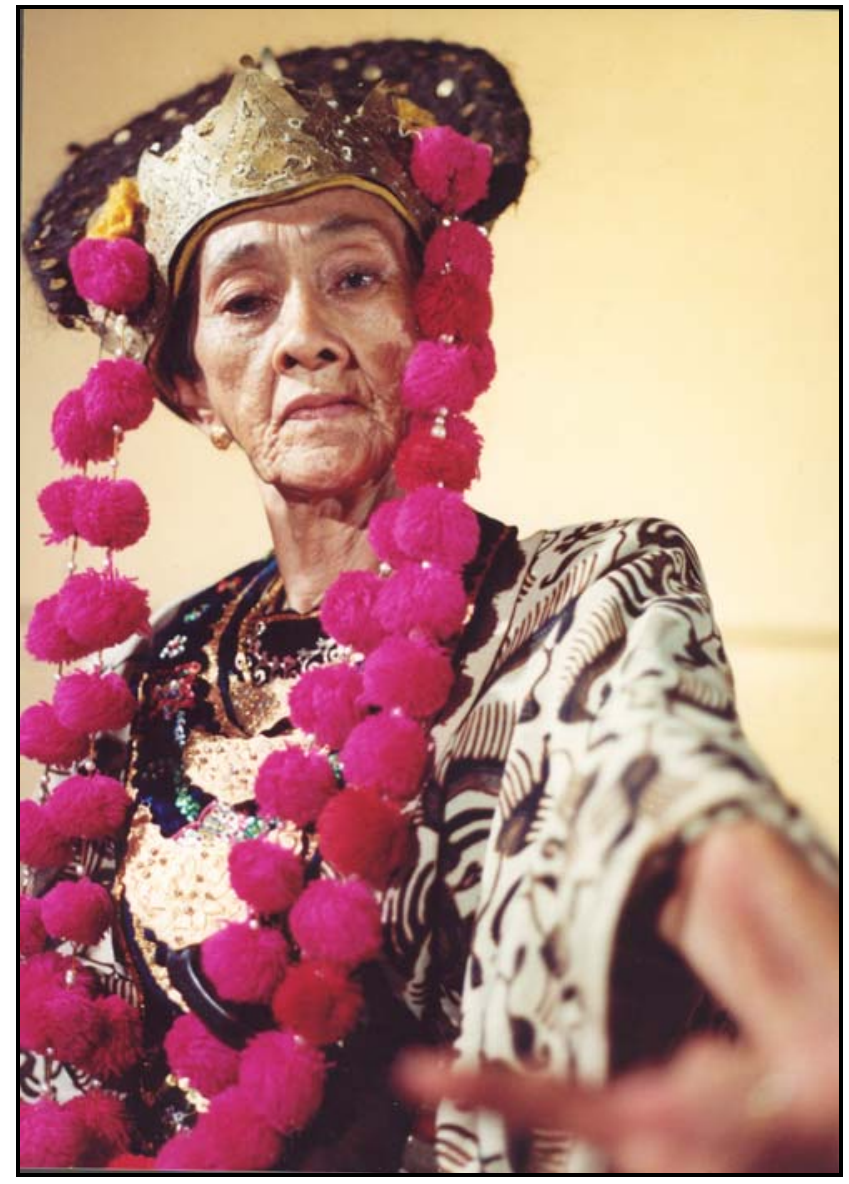

Ibu Sawitri dancing Klana Bando Patih, Losari/Cirebon, 1997 
painted white, with two large 1970s-style windows on either side of an old, dilapidated traditional teak door that looked out onto a large dirt-yard pendopo. The decision to seek out Ibu Sawitri to see if she would agree to teach me her dance had been a leap of faith. The journey there, and the resulting complex, fluid and always changing relationship of teacher, student, mother, daughter, insider, outsider, agent, object and friend, changed my life forever.

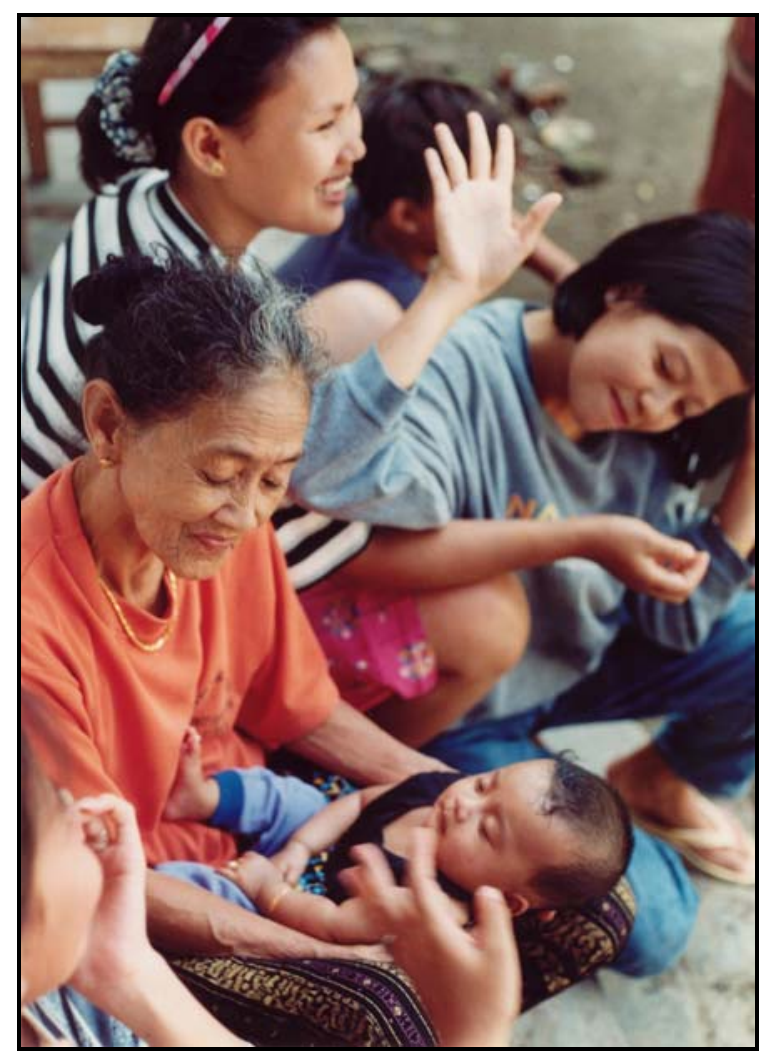

Ibu Sawitri with family in Losari/Cirebon, 1999

\section{Finding Ibu Sawitri}

The first time I saw Ibu Sawitri, or Mak Etik as I was later to call her, was in 1992 on a faded, old colour photograph with rounded corners typical of the mid to late 1970s. Mas Untung, a senior member of Rendra's Benkel Theatre, showed me the photograph over tea in his home in Yogyakarta. ${ }^{3}$ The image on the photograph was of a masked dancer striking an energetic pose with legs wide, torso bent back, and arms defiantly

\footnotetext{
${ }^{3}$ Rendra is a famous Indonesian poet and playwright based in Depok/Jakarta where he lives and works with his theatre company Benkel Teater.
} 
outstretched at the sides. The dancer was wearing a white mask with a black beard, large eyes and nose, a black headscarf and a brightly patterned megamendung batik cloth tied around her waist. The mask she was wearing was Temunggung, the semirefined prime minister character. The performance was taking place outdoors on a stage under a blue tarpaulin surrounded by local village people. I didn’t understand the details of what I was looking at, but I did notice a mask and body that regardless of the tattered, faded nature of the photograph, showed an incredible energy and expressiveness. The dancer's arms, although thin as sticks, together with the rest of her body, radiated a strength and arrogance befitting the masculine mask.

This photo, over and above the handful of recommendations I had received from friends in the Yogyakarta dance and theatre community with whom I was living and learning dance at the time, made me decide to look up Ibu Sawitri and ask her if she would become my dance teacher. Didik Ninik Thowok, a famous transvestite dancer and comedian in whose studio I was living and learning dance at the time, was particularly enthusiastic about the insights and benefits that could be gleaned from the process of learning dance in a traditional context during extended visits. During the early stages of his own dancing career he had learned a different style of Cirebonese mask dance from an old master who had since died. Didik had been hoping to learn with Ibu himself but due to his busy schedule and Ibu's failing health never had the chance. He did, however, become a patron and was very supportive and generous of Ibu, particularly during the final stages of her illness.

Equipped with a photograph and a vague set of directions about how to find Ibu Sawitri's house, I set off just like all those other 'transcendentally homeless' adventurers of the past. The first part of the journey was routine, since I had travelled between Yogyakarta and Jakarta many times before. This journey was no different. I had the usual conversation with fellow passengers who wanted to know everything about me, especially why I wasn't married and why I was travelling alone. I gave my standard responses in between sips of iced tea and added the newly acquired name cards to my ever-growing stash of people I would probably never meet again. As a 
westerner who speaks fluent Indonesian with a Javanese accent I was a novelty and a curiosity. My white skin, light brown hair, blue eyes and $1.65 \mathrm{~cm}$ height, which is average in Australia, even short in Holland or Germany, put me almost one head above most people I met and thus made me very conspicuous. Hey bule, mau ke mana? Hallo Londo! I luf you! Hey Mister, or the other variation, Hey Muster! ${ }^{4}$ I used to hate the last one because it sounds too much like monster, which on a bad day desperate at the lack of privacy and millions of eyes watching, I would sometimes feel like. But then there are days in Australia when I feel like a monster so I suppose it's all relative.

Although welcome and flattering when I first arrived in 1983 as a self-conscious teenager desperate for attention, this superstar status had become increasingly hard to bear the longer I spent in Indonesia. I could not go anywhere unnoticed. I couldn't sit on a train reading a book or simply staring out the window. I was eternally engaged in the same conversation except that the faces changed. I did meet many amazing people that way and I am conscious of how ungrateful and superior it may appear to complain about this popularity, which has such a long and contested history. I am aware that my position as Other in this context, although not always easy, is infinitely more empowering than being an Other in a western context. Yet, as occidental I was placed in a box, from which I could not escape regardless of how long I spent in Indonesia. I was and would always be, to anybody who didn't know me, the newly arrived bule or londo, a status which comes with a whole range of assumptions that I couldn't evade, no matter how hard I tried.

The journey from Cirebon train station to Losari, approximately an hour's drive towards the border separating West Java from Central Java, brought me headlong into the reality of what I was about to undertake. After much hustle and bustle, questionasking and being led off in fifty different directions, I eventually worked out how to get to the bus terminal that would then connect me by bemo (a diesel Hiace van) to Losari.

\footnotetext{
${ }^{4}$ Bule literally means albino buffalo but is the commonly used term for western foreigner. In Central and East Java foreigners are referred to as londo, from the word Belanda, which means Dutch. The way to distinguish between nationalities is to add the name of the country, i.e. londo Jepang, londo Inggris, londo Jerman etc.
} 
Hot, sticky and tired I was finally sitting in the middle row next to a window. In typical Indonesian public transport style the van waited in the sweltering heat for the maximum passengers and then proceeded to travel along at breakneck speed, overtaking other bemos in order to compete for passengers who, in complete defiance of the laws of physics, always found room. The passengers I encountered that day and on many occasions since were mostly made up of young men in torn, dusty old sneakers, faded jeans and t-shirts often adorned with some kind of heavy metal insignia, school children of all ages in national uniform, old weather-beaten women in tired traditional dress, young women dressed in last year's Lebaran fashions, now faded and torn. ${ }^{5}$ The women had by far the biggest cargo made up of krupuk (prawn crackers), dried fish, chickens, vegetables, plastic ware, bundles wrapped in batik slendang (shawls), and all manner of packages, the contents of which I could only guess at.

I sat with my bag propped on my knees, wedged tightly between the window and a young schoolgirl who kept stealing sidelong glances at me. The smell that pervaded the van was a combination of pungent dried fish, shrimp paste, dried and raw onions, salty sea air, diesel fumes, sweat, and the ever-present kretek (clove) cigarette smoke. These smells emanated potently and immediately from the goods stashed in the minibus, and also wafted in through the open door and windows from local industries scattered along the roadside, as we flew along. ${ }^{6}$ In this context the passengers didn't speak to me, they just stared. My presence in their midst was decidedly out of the ordinary, given that this bemo route was not heading towards any obvious tourist destinations. In my usual attempt to make myself invisible I in turn stared out the window. The landscape to the right of the main road was flat and vast, interspersed with rice-fields, local industries and, in the small towns, flanked by open shop fronts and markets. To the left of the road was the ever-present north coast dotted with local fishing ports full of multicoloured fishing trawlers.

\footnotetext{
${ }^{5}$ Lebaran or Hari Raya Idul Fitri is the Muslim celebration at the end of the one-month fast of Ramadan. Muslims all over Indonesia buy a new set of clothes to celebrate this event. For some people of lower economic status this occasion often represents the one time of the year they will buy new clothes.

${ }^{6}$ Fishing, prawn farming, onion growing and drying, and sea-salt production, are the prime industries of the Cirebon-Javanese north coast.
} 
A few young schoolgirls, including my immediate neighbour started to giggle, and I heard them speaking in a hard, explosive-sounding, unfamiliar Javanese dialect. Kepriben, idung londo iki kok gede banget! Soon the entire van was laughing. An old woman pointed at her own nose and then at me. I started to rub my nose, thinking I had some dirt smeared on it, but this action just made everybody laugh more. Then I understood, they thought my nose was odd. I didn’t think I had a particularly long nose, but compared to the broader, flatter Indonesian noses and to those unfamiliar with regularly seeing westerners close up, my nose must have appeared like some strange discoloured mutation. Iya ya, londo idunge gede ya?! This comment by me was followed by peels of laughter and a barrage of questions, now that the passengers knew I could speak Indonesian, even a bit of low Javanese. This ice breaker, or nose breaker as I should say, ice being furthest from reality, was welcome, because in no time at all I was able to establish where to get off the bemo and how to find Ibu's house.

One of the passengers got off with me and was telling the becak drivers to take me to the mask dancer's house. O Bu Witri, iya ya penari kedog, ya ya tahu, tahu, sini, sini ikut saya, saya antarin. They all knew Ibu Sawitri, her family being the only active mask dancers left in Losari, a small town on the outskirts of the Cirebon district. The sensation of wind blowing through my hair, the gentle squeaking sound of the becak wheels turning, and the pleasant chatter of the becak driver behind me, had a calming effect, helped no doubt by the knowledge that I had, with the help of the local people, managed to find a way to Ibu's house without any major drama. The languid sleepy inactivity of a hot, post-lunch Javanese village afternoon floated past like a dream interrupted only by the sudden jerking of heads and the usual calls at the sight of a bule in a becak. The initial calm I felt was slowly evaporating and soon replaced by a lowlevel nervousness at the shock I would cause when I arrived in the village. I was comforted by the knowledge that there had been numerous other western and big-city visitors, so my appearance would not be a complete novelty.

Yet my arrival did cause something of a commotion. Ibu Sawitri's niece, Mak Mutri, went into a right tizz at the sight of me. She sent Heri, Nur and Sri, three of her five 
children, on a mission to find Ibu, who was not at home. I was seated in the guest room and kept reassuring Mak Mutri that there was no hurry. She was visibly flustered and was dashing in and out of the front room of Ibu's house with tea and all manner of jars filled with biscuits, peanuts and krupuk. Ibu arrived soon after also looking alarmed. She had been helping a neighbour with a collective cooking session for an impending wedding. Later that day she told me how relieved she was that I could speak Indonesian and that she had been worried she would have to turn me away as she had done on one other occasion when a foreigner who could not speak Indonesian had come to study with her. And that's where it all started. She agreed to become my dance teacher after she had found out more about me and all about the other dances I had learned and told me all about her other students and her own dancing history. From there we agreed on tuition fees, accommodation, food costs, and a date when I would return for my first two weeks of instruction.

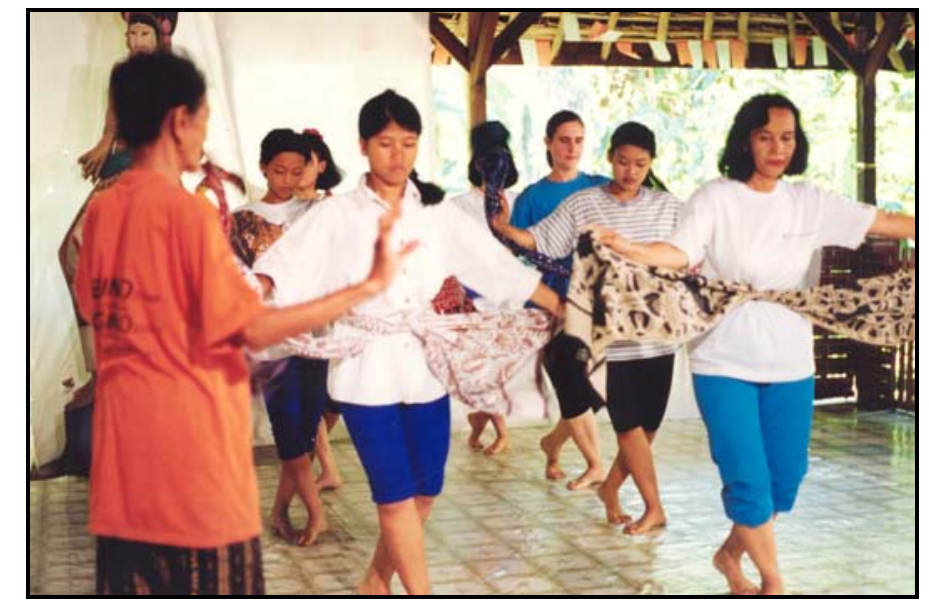

Ibu Sawitri teaching family and students, Losari/Cirebon, 1997

\section{Topeng Losari: Dancing in Context: Changing Social Conditions}

When I first met Ibu Sawitri she was in her late sixties. She was a descendant from a long line of mask-dancing families and was the only surviving member of her generation. She had been married six times and had left her last husband in Palembang on the Island of Sumatra at the age of 50 in order to devote herself fully to her maskdancing vocation. It had been her father's dying wish that if she failed to pass on the dance, she was to bury the masks according to local custom (Sawitri 1996, 1998) . 
When I first met her she was busily teaching the younger generation how to dance and play gamelan. Topeng Losari had almost died out in the 1960s but was brought back into existence with the help of a handful of Jakartan patrons of the arts and artists who were concerned at the rapid rate at which traditional arts in Indonesia were disappearing.

One of the main reasons so many art forms had disappeared was the trend towards a more conservative Islam. This growing conservatism was brought about by closer ties between villages to the middle-class urban Islamic party Muhamadiyah, with links to Islam imported directly from the Middle East via radio, television, books, and more frequent travel to Mecca. This trend had a profoundly negative impact on traditional art forms. Traditional artists were accused of being tahyul (inspired by animism) rather than the new rational form of 'pure' Islam aspired to by Muhamadiyah. Traditional ceremonies like bersih $\operatorname{des}^{7}$ associated with the rice harvest and ancestor worship were increasingly discouraged from as early as the 1930s, and the discouragement gained strength in the 1950s and 1960s (Masunah 2000). Topeng performances were an integral part of these rituals, and, with their demise, Topeng became increasingly marginalised.

The second most dramatic attack on traditional art forms was the 1965 communist coup and subsequent massacres of suspected communists. Prior to the coup Indonesia had the largest communist party in the world outside China. Artists and their suspected connections to the socialist artist movement $L E K R A$ were thus under suspicion. ${ }^{8}$ Out of fear of being accused communist, the Topeng Losari mask dancing troupe stopped performing altogether after the 1965 military crackdown. It wasn't until the late 1970s that the troupe was rediscovered by Jakartan patrons of the arts. Another reason the traditional arts were starting to wane was the advent of television in the early 1960s and an increasing number of households obtaining radios and cassette recorders that

\footnotetext{
${ }^{7}$ Bersih desa is a village cleansing ritual whereby dangerous spirits are warded away from the village by offering food to the danjang desa (guardian spirit of the village). Food offerings are made at the gravesite of the danjang desa (Geertz 1976).

${ }^{8}$ For more information on LEKRA see Foulcher (1986).
} 
introduced different forms of popular entertainment, such as Dangdut, ${ }^{9}$ and local and international pop and rock music, to rural areas. In the past, daytime mask dance-drama performance and all-night Wayang Kulit (shadow puppet) performances were the highlight of ritual occasions, such as marriage, circumcision, and harvest ceremonies. In the 1960s these traditional performances were rapidly being replaced with popular modern entertainment forms such as bands, popular music played through large sound systems, and outdoor film screenings. The hire of these modern forms of entertainment was considerably cheaper than paying and providing food for an entire dance troupe (Sen 1994; Sen and Hill 2000).

In1992, Ibu Sawitri and her mask dancing troupe Purwakencana rarely performed in a local context, except for annual local government-sponsored occasions, or for each other, that is other gamelan players or family members. Most performances were sponsored and organised by patrons of the arts in larger cities or government bodies wanting to showcase traditional regional arts as a manifestation of Indonesian cultural unity. The troupe was even invited as far afield as New York, sponsored by UNICEF to highlight traditional arts from the region of Cirebon, West Java.

The fifteen-year break, and the change in performance context and audience, had a major impact on the Topeng Losari form. In the past, performances were all-day events that would begin with the main mask characters of the Panji repertoire being danced solo. Panji, the main protagonist and archetype of the ideal refined male, would always start the proceedings, to be followed by increasingly less refined characters, concluding with the final return to a refined character. ${ }^{10}$ This part of the proceeding served as the performance introduction and is a danced form. Following this introduction of characters was a complete mask drama detailing the adventures of prince Panji.

\footnotetext{
${ }^{9}$ Dangdut is a form of contemporary popular music inspired by Indian Bollywood musical scores. The tabla beat with its onomatopoeic dang-dut-dut-dang sound is where the music acquired its name. Dangdut began as a youth subculture in the late 1960s and is still very popular among the Indonesian working class and in rural areas. Rhoma Irama, who was one of Dangdut's first stars, is still massively popular today. The Dangdut song lyrics range from romance, heartbreak and social critique to Muslim morality (Pioquinto 1995).

${ }^{10}$ Panji is a refined prince character and represents the same archetype as Arjuna of the Mahabharata and Rama of the Ramayana repertoires (Holt 1967).
} 
Traditionally the mask performances were held during the day and followed by an allnight Wayang Kulit shadow-puppet performance by the same dalang. ${ }^{11}$

Nowadays, given the changed performance context and audience, the troupe mainly performs the dances together with a very short segment of the Panji drama inserted in the middle. The dances have also been radically shortened. In the past the choreography for the main characters was up to an hour and a half in length. The dances performed nowadays are an average of fifteen minutes in length when performed in isolation and up to a maximum of thirty minutes when performed as a dance/drama 'package'.

Topeng Losari has undergone a radical transition in the performance context. Originally it was performed in the surrounding villages, as a ritual occasion to bestow blessings and ward off evil spirits on a given ceremonial occasion. Now it is predominantly a performance commodity of traditional Cirebonese mask dance that is marketed at local (mostly big city) or international arts festivals.

Were it not for this transition in context and audience, Topeng Losari would have disappeared, as have many other traditional art forms in Indonesia. Ibu Sawitri and the troupe's ability to survive was due to their willingness to adapt and grow with changing conditions. When I spoke to Ibu about the meaning of various movements, she confessed to not knowing them, but that her father had known. She herself was worried that the full meaning, in other words her meaning of the dance, was not going to be passed on to the next generation. ${ }^{12}$ Now the next generation is busily making the dance their own and has no doubt a clear sense of what the dance means to them, based on their experience of it. Many members of the younger generation would have mainly observed and participated in performances at festivals, outside the traditional village context, and thus have a very different sense of the form and its meaning than Ibu Sawitri did. From early childhood, she would have sat among the gamelan players

\footnotetext{
${ }^{11}$ In other mask dancing areas of Cirebon it is said to represent a life cycle starting with infancy through to old age, the fragility of these states being expressed through refined character representations. As with characters of the Wayang repertoire, the danced masks represent archetypes ranging from the most desired to most undesired character types. Their function was to confirm acceptable social behaviour in the community (Suanda 1983; 1988).

${ }^{12}$ Much of Ibu's traditional dance knowledge has not been passed on to the next generation because it was no longer practical or relevant in the new performance context (Sawitri 1999).
} 
watching the proceedings at ceremonial occasions, as well as during the ngamen (busking) tours during paceklik (literally, empty stomach), the time of scarcity before the rice harvest (Suanda 1983; 1988).

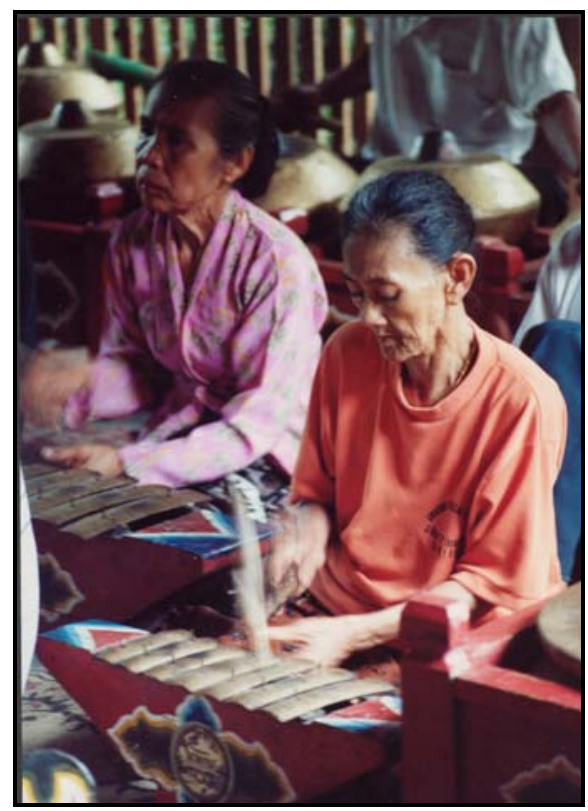

Ibu Sawitri participating in gamelan rehearsals Losari/Cirebon, 1997

Each generation of dancers had, and has, different interpretations and different experiences of the dance based on the context and time in which they were and are performing. In other words culture, even traditional culture, is dynamic and ever changing. The minute a culture or tradition becomes static and unchanged it dies and becomes a museum piece. As Schechner puts it:

The slipperiness of 'culture' as a definite term is due to extreme dynamism, lability, and volatility of any given culture. Every culture is always changing, even Japan during its period of so-called isolation that ended with the Meiji restoration of 1868 . What is meant by 'culture' is actually a snapshot, a stop-frame of an ongoing historical action...Attempting to fix cultures or stop them from changing is like trying to annihilate history $(1991,306)$.

Ibu Sawitri's decision to accept me as a student was first and foremost an economic one. Given that the troupe was reliant on invitations from the outside to perform and thus earn money, there was no certainty as to when such occasions would come about. The troupe could no longer rely on set ritual months with guaranteed work as they had 
in the past. In between gigs, Ibu Sawitri and the other troupe members earned money through an endless variety of odd jobs such as rolling cigarettes, peeling onions for local industries, cooking and selling food, selling clothing door to door, and working as seasonal labourers in local rice fields, to mention a few of their varied sources of income.

Teaching dance to outside students was thus a means of making a living from her dance. When I first started studying dance in the village, a price was negotiated for the dance tuition that included food and accommodation. Not surprisingly it was more than the cost for local students. I was a westerner and there was no escaping the fact that I was in a privileged position economically when living in a small village in Java, even though I was an artist on a low income in my own country. I was accepted as a student, and later on as a daughter. ${ }^{13}$ The fact that I was a westerner who had the financial freedom to come and go put me in a position of power I had to be careful not to abuse. As Said reminds us:

For a European or American studying in the Orient there can be no disclaiming the main circumstances of his actuality: that he comes up against the Orient as a European or American first, as an individual second. And to be a European or an American in such a situation is by no means an inert fact. It meant and means being aware, however dimly, that one belongs to a power with definite interests in the Orient, and more important that one belongs to a part of the earth with a definite history of involvement in the Orient almost since the time of Homer $(1996,28)$.

\section{Passing on the Dance}

From 1992 until my last visit in early 2002, I regularly spent extended periods of time learning the dance and living with Ibu Sawitri’s family. During these visits I learned four of the five dances that were being taught by Ibu Sawitri. In the beginning I learned one dance per long-term visit, and later would revise and improve those I had learned. The younger generation of her family and myself were taught dance in an outdoor covered studio space (sponsored by a patron) at the back of the house, accompanied by poor recordings of live gamelan music from past performances and live gamelan

\footnotetext{
${ }^{13}$ Teacher-student relationships have an ancient history in Java. Committed students are often included into family structures and, like real family, are expected to help the teacher/parent whenever possible. So even though my friendship with Ibu Sawitri was a genuine one, there were certain political motivations in cultivating strong bonds of loyalty (Geertz 1976).
} 
practices on Sundays. Learning the dance involved Ibu Sawitri and/or several of the more accomplished dancers dancing at the front, while those learning stood behind and copied the movements. Sometimes Ibu would watch and give feedback. This often involved her jumping up and slapping the body part of the learner that wasn’t cooperating. The usual comment was the movement was either mati (dead) or salah (wrong). She would then demonstrate how it was supposed to look and make the learner copy it until she was satisfied. She might even manipulate the body to give the feeling of the movement in a direct way. The main mode of learning was by endless repetition and observing the teacher's movements.

Ibu Sawitri's experience of learning dance was very different. When she was growing up, her father's mask dancing troupe was always busy. During the festival months they performed almost daily and in the low season went on busking tours. At the age of nine Ibu was invited to perform, and from years of watching knew how to do it. Experience and skill are gained by performing. It was exceptionally important to be known as an excellent dancer, particularly if you were the dalang of the group, as was Ibu's father. Competition between groups was fierce and in order to survive one had to be the best. A number of ascetic practices were employed to ensure this kind of success. The dalang, dancers and musicians alike practised ritual fasting, ${ }^{14}$ and other ascetic feats of endurance, such as living in a tree or down a well for long periods at a time, or eating a cup of chillies a day for a given period, to mention a few (Sawitri and gamelan players 1996). The feats were believed to endow the person carrying them out with special magical powers, one of which was the ability to attract audience attention, which would in turn guarantee continued work.

None of the younger generation of dancers had participated in ritual fasting, although they were aware of its function. Ibu called the younger dancers the generasi supermie (instant noodle generation) and said it was pointless to teach them the more ascetic practices related to the dance because, one, they weren’t strong enough, and two, they

\footnotetext{
${ }^{14}$ Puasa Wali is a ritual fast that begins with a three-day fasting period and then builds up gradually over time to the maximum of 40 days. The only food consumed during this fast is a small cup of water and half a banana per day (Masunah 2000; Sawitri 1999).
} 


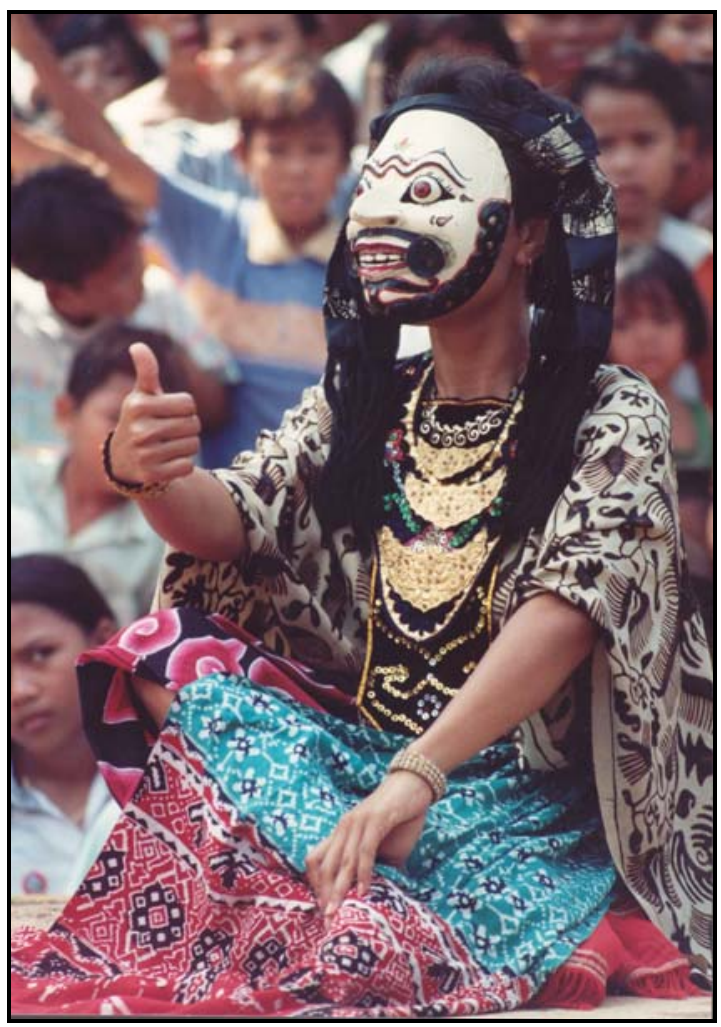

Kartini dancing Temunggung Magang Diraja at a gamelan member's son's circumcision celebration, Losari/Cirebon, 1997

didn’t need them any more (Sawitri 1996). There are other ritual practices involved in staging the dance that the younger generation have learned and still practice, such as burning incense and praying to the Wali Sanga, ${ }^{15}$ whose spirits are believed to reside in the gamelan instruments and to guard the four corners of the performance space. Masks are also traditionally believed to contain the spirits of the characters they represent and are given incense at regular intervals according to the Javanese lunar calendar. When Ibu dances, she believes that she is entered by the spirit of the mask. She describes it as being 'danced’ by the mask (Sawitri 1993, 1998). ${ }^{16}$

\footnotetext{
${ }^{15}$ Wali Sanga are the nine holy men believed to have introduced Islam to Indonesia. Islam was spread through the traditional arts and there clearly exists a strong connection, certainly in the minds of the traditional performers. Sunan Kalidjaga is generally considered the most important and powerful of the Walis and is usually credited with founding the Wayang shadow play and therefore has a special protective function in relation to the traditional performing arts (Geertz 1976; Ricklefs 2001).

${ }^{16}$ Kathy Foley (1985) has observed this phenomenon in her research with traditional dancers from West Java. She refers to it as the 'empty vessel theory'. According to this theory, when commencing to dance, the traditional dancer lets go of the ego to make space for the spirit of the dance to enter and lead the body of the dancer.
} 


\section{Embodiment or Cannibalism: Encounters in the Contact Zone}

When I went to study dance with Ibu Sawitri I had no plans other than that. Building on the dance styles I had already studied, I wanted to learn the technique of dancing with masks. Soon after starting to learn dance in the village, I realised that Ibu was struggling to keep an art form alive that to me looked well on its way out. Old gamelan musicians were dying without being replaced by younger ones. Ibu was the only person who held the information that needed to be passed on in order for the dance to survive into the future, or so I thought. She had knowledge about the dances' history and meaning, which she said had not been passed on to the next generation yet. Partly in response to my own need to 'master' and 'understand' the dance, which was new and strange to me, I did what all colonials, anthropologists, ethnographers, and explorers of the past did: I recorded the dance and attempted through interviews to document as much knowledge and history about the dance as I could. During the first few long-term visits I made amateur attempts at recording the full mask repertoire on video and DAT cassette. Later on I decided it would be a good idea to make a documentary about Ibu's life and the dance. In attempting this I spent many months between 1996-1999 filming the dance and interviewing Ibu and her family with my ex-partner, a cinematographer. He shot many hours of exquisite footage but to date there is still no documentary film. The footage remains archived on my mini esky, which I guard with my life. The fact is I'm not a filmmaker. I'm a dancer, contemporary performer, visual artist, and academic, and these are the venues through which I have processed the knowledge of my experience of living and learning dance with Ibu Sawitri. ${ }^{17}$

\section{A Change in Perspective}

Through the process of making Troppo Obscura, I no longer see my engagement with Ibu and her dance as driven by the need to 'save' a 'dying' art form from 'extinction' (in keeping with a colonialist concept of benevolence); rather I see it as a cross-cultural dance of shared space in which our subject positions and identities are in an ever-

\footnotetext{
${ }^{17}$ The footage remains and with help from professional filmmakers I am hoping one day to make a documentary, at the very least to record the footage onto DVD and return it to Ibu's family. During my last stay in 1999 I employed a professional sound recording team to record the full dance repertoire. I handed Ibu the original master copy and a large number of CD and cassette copies for use in teaching.
} 
evolving choreography of rearticulation. I am attempting to make this process visible in my performance work and particularly so in the Troppo Obscura project. In the following quote, referencing Spivak and Heidegger, Chambers dances this fluid complex choreography in words that echo my intention here.

In my response to an impossibility, the impossibility of speaking for the other, I mark the particular, the particularity of my voice, body of thought and way of being, and from within the global web or 'Westernisation' of the world speak from somewhere, not everywhere. This is to seek to inscribe that impossibility into my language, understanding it not as a critical failure or closure but rather as something that exposes me to the interrogation of the presence of the other, and thus to the historical bounds, cultural specificity and political limits of my self. It perhaps means to live in another country where 'to confront the subaltern is not to represent them, but to learn to represent ourselves'. To live in another place, is to begin to inhabit the ambiguous territories that draw us out of our actual being towards a way of becoming in which no one history or identity is immune from a new and diverse 'worldling of the world' $(1996,59)$.

In keeping with Chambers’ position, it appears that the more important question to ask ourselves in the face of the Other is: 'Can I speak myself?' Speaking our 'self' in the process of engagement with the Other is in the end all any of us can hope to achieve.

What I have tried to do in my performance work and writing is to locate my body as the filter that receives information, internalises, interprets and 're-cites' it, based on a very personalized set of building blocks that constitute 'me’ (Chambers 1996). To complicate matters these building blocks of identity formation and subject positionality are in a constant state of becoming, so that everything is always in a state of flux and change, making it impossible to speak in absolutes. Given that it is only just possible to speak ourselves in the here and now, and knowing that this position is fragile and changeable, how can we contemplate being able to speak for an Other? I cannot speak for Ibu Sawitri. What I can do, however, is speak about how I remember my own personal experience of engagement with her, and how that challenges and changes the foundations on which I now stand. I have attempted to place the 'somewhere' of my body and way of being in the world by telling that story, literally and metaphorically, within the installation and this text. I hope that this kind of engagement is a 'speaking to, not a listening to or speaking for, the historically muted subject of the subaltern woman.’ I also hope that with this process I am 'systematically unlearning my postcolonial, intellectual, female privilege’ (Spivak 1988, 295, her emphasis). 


\section{Collisions in the Contact Zone}

At this point I remember a segment of archival film footage film I came across while doing research in the Dutch archives and which was to become the inspiration for the Wall projection of the installation, in which I perform Indonesian mask dances in colonial dress. The scene was of a colonial woman dressed in white, turn of the nineteenth-century colonial dress, with a larger white feathery hat, stepping out of a car with other Dutch colonial residents, and narrowly escaping the path of a thin, darkly clad Javanese woman walking along the footbath carrying a load on her head. In the film, the paths of the voluminous white colonial woman and the thin Javanese woman cross without engagement. In this encounter these women's spaces did not converge; there was no meeting place, no awareness or acknowledgement of each another's existence or inhabited worlds. This footage is testimony to the reality of colonial denial. The very foundation of colonialism is the inhabiting of the Other's world as if it is 'unreal', 'uncivilised' and thus needing to be inhabited with the 'real', the 'civilized westerner’ who has ‘truth’ and enlightenment on his/her side. The psychological underpinnings of this logic appear to run along the lines of: 'I am real, I am the centre of my universe, your Other existence threatens to topple my existence in the centre, and therefore I must annihilate, or at the very least subordinate, you’.

I remember choreographing a dance in my head in reaction to what I was watching in the archives. I imagined a Javanese family sitting down to eat in their home, when through the door a group of white clad colonial agents waft into the space full of confidence and an air of propriety. They move around the table looking at the family with gesticulating moves and raised eyebrows. The Javanese family looks at each other in concern and stand up and begin to speak to the intruders. They respond with peels of surprised laughter at the quaint language issuing from the family members' mouths. The white clad people start to touch the hair and bodies of the family, who duck and shy away. In response they are gripped with more force and a dance begins with the Javanese being manipulated into ther forms and shapes of tables, lampshade holders, stools to be sat on, drapes around the shoulders, shapes on which to rest one's feet. And so the dance struggles on. Each time the Javanese escape a pose and start to attack, 
more of the intruders group together and manipulate them into another shape.

Eventually the family members resist less and less until they are malleably shaped into whatever form the intruders wish. At that point I stopped in disgust, and returned my gaze despondently back to the video screen. Ghassan Hage divides this spectrum of the fear of European otherness into two types, 'the other of the will' and 'the other of the body'.

The other of the will is the cunning other, the competitive other, the manipulative other, the conspiratorial other, the other that can thwart my plans and undermine me, the other who, deep down, I fear might be superior to me at least with regard to intelligence. The epitome of this other is, of course, the anti-Semitic figure of the Jew. It is also the product of a racism very specific to it, the racism of extermination.

The other of the body, on the other hand, is an unambiguously inferior other (except, perhaps, when it comes to sexual prowess), inferior in terms of intelligence, inferior in terms of technical know-how, inferior in terms of capacity to be productive (eg the category of 'the lazy other'). The epitome of this was the colonial portrayal of the black African. Likewise it is also the product of a very specific type of racism, the racism of exploitation $(2003,9)$.

Hage goes on to argue that because the other of the body was 'all body', she/he was exploitable as such and didn't pose a threat of the mind, which would have called for extermination. That is not to say, however, that colonial exploitation didn't in many cases also cause extermination; it clearly did. As Hage notes, once the Other is contained, controlled, eliminated or radically reduced in numbers, politically squashed and powerless, a substantial number of colonisers start 'to love those "socio-politically dead Other[s]" and "yearn” to "preserve” their culture'. He refers to this as a "political necrophilia” specific to the evolution of colonial culture' $(2003,9)$. This yearning to be the 'benevolent' guardian and saviour of the down-trodden and helpless, he argues, relied on the knowledge that they were and would remain disempowered and moving towards extinction, justifying the superior position of 'saviour' with 'might' and 'right' on their side.

The way of dealing with the fear unleashed from a collision of cultures in the past, and to an extent in the present, was/is to counteract it with the violence of colonial invasion and imperialism. Ironically the site of this collision and the resulting space of intersection, of Other and self, self and Other, can a open up a new space for 


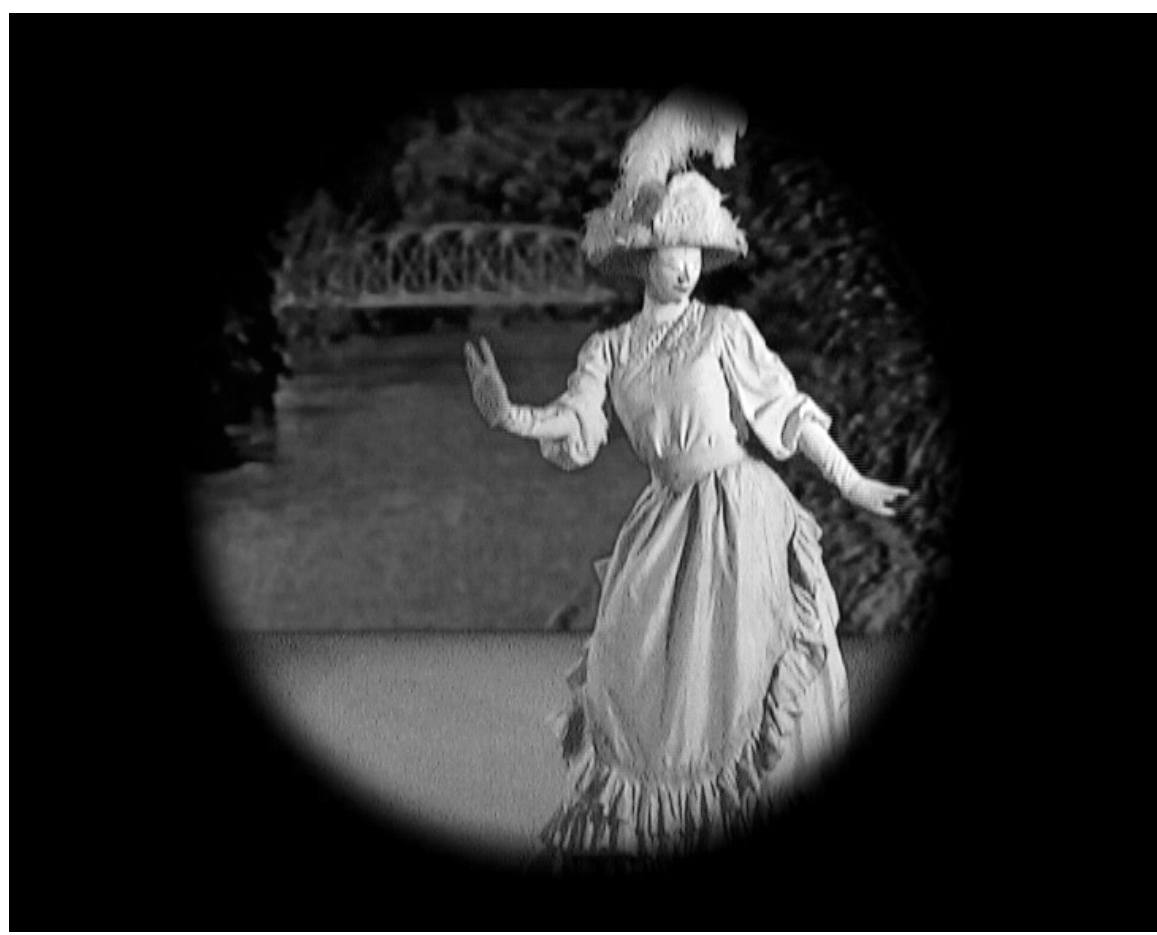

Wall Projection, Troppo Obscura, October 2002

interpretation and ways of being in the world. The shaded-in convex shape of two overlapping circles - the stage- of coloniser/colonised, ex-coloniser/ex-colonised-is what I like to think of as Pratt's 'contact zone'. Pratt defines her use of the term ‘contact zone’ as:

an attempt to invoke the spatial and temporal copresence of subjects previously separated by geographic and historical disjunctures, and whose trajectories now intersect. By using the term 'contact,' I aim to foreground the interactive, improvisational dimensions of colonial encounters so easily ignored or suppressed by diffusionist accounts of conquest and domination. A 'contact' perspective emphasizes how subjects are constituted in and by their relations to each other. It treats the relations among colonizers and colonized, or travelers and 'travelees,' not in terms of separateness or apartheid, but in terms of copresence, interaction, interlocking understandings and practices, often within radically asymmetrical relations of power $(1992,7)$.

I like to think of the 'contact zone' as a dance floor made up of the overlapping sections of two diverse circles that represent a particular history, culture, and identity. I imagine a dance taking place on this convex parqueted dance floor between the egos of those two overlapping circles now forced to share the same space. The dance begins, bodies approach and recede, circle one another curiously and cautiously, touch and bump, stumble and get up again, push and pick up, caress and shield, dance and copy, on and on and on in an ever-changing and emerging 


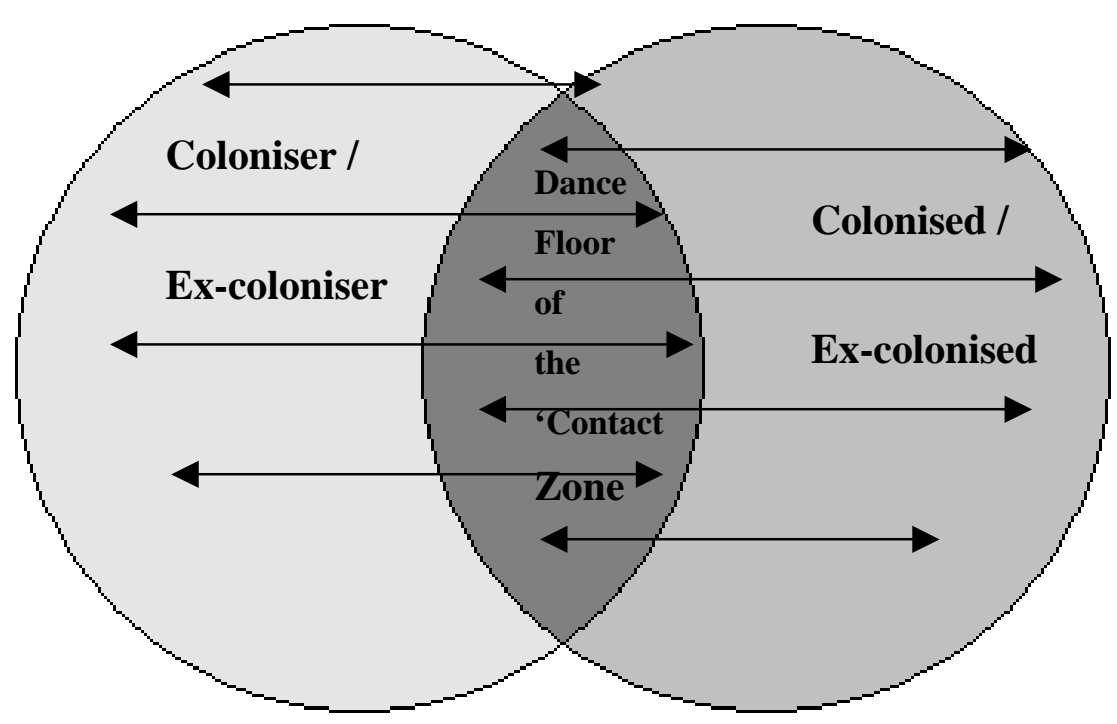

Dance Floor of the 'Contact Zone'

dynamic of interacting bodies. This dance might create any number of endings. It could end with one of the dancers bound, gagged and forced to watch the other dance in glittering costume to spectacular music. Or it might end with one of the dancers forcing the other dancer to follow his/her specific movement style. Another outcome might involve one of the dancers copying the other's movements and using them in whatever way they like, while the other dancer would resist, sticking rigidly to their original movement form without deviation. A novel outcome would be for the dancers to relax into a dance of constant motion and transformation in which both dancers are free to express their movement style and to be influenced and moved by the other. It may be a dance where the dancers try on each other's dances for size and see how they feel in their bodies, thus finding places to put this new information in their bodies and in their minds. In this process they may find a language with which to speak and dance with one another without becoming one, maintaining difference with a new embodied awareness of the Other, who is still Other but no longer feared.

By embodying as distinct from cannibalising the Other, whether it be through language, dance, music, or art, we are opening up new spaces for multiplicity and diverse ways of 
being in the world. Making a space in our bodies to let the Other in is an act of expansion, rather than denial and annihilation. This space allows for an open-ended 'cross-cultural conversation that attempts to distinguish and articulate the contradictions of postcolonial mentalities and material worlds' (Sears 1996, 42). Cannibalism, on the other hand, being the European trope most closely tied to the deep-seated psychological fear of the Other, is in fact what the colonisers metaphorically do to the feared Other (Fusco 2001, 111). The coloniser greedily finds out everything there is to know about the Other, which is a kind of invasive consuming, with the stated aim of labelling exactly 'who they are' and thus diffusing their threat. This labelling pronounced after a swallow, burp and a wiping of the mouth, is an annihilation and a boxing-in of the other's right to exist in a state of transition and change in the same way that the coloniser allows him/herself to exist. It is a denial of space.

\section{Dancing the Contact Zone with Ibu}

So what does the dance between Ibu Sawitri and I look like? Our dance traverses the boundaries of age, race, history and privilege. The relationship we established was primarily one of teacher and student. Within this dynamic we developed a close friendship and I was eventually accepted as an adopted daughter into her family. The feeling was mutual. The embodied experience of learning dance with Ibu, and living in her house with her family, instilled in me a sense of belonging, solidarity and connection with Ibu and her family. This experience was heightened by the growing awareness of how these relationships were becoming manifest within my own body.

Half a year after Ibu’s death, at home in my studio rehearsing for an impending performance, I had an experience that dramatically changed the way I understand dance, embodiment and human connection. On this particular occasion, in keeping with my rehearsal routine, I was practising one of the mask dances by way of warm-up. As I was moving through the dance, I became aware of an image of Ibu's dancing body. At the same time, as I was engaging in the dance movements I could literally feel Ibu in those parts of my body. It was a strange combination of holding an image of the movement in my mind and at the same time feeling Ibu in that actual part of my body. As if her arm 
was my arm. As if my body was remembering Ibu. By dancing the moves I was evoking Ibu in my body.

I was deeply affected by this experience and it is the closest I have come to a moment of what I understand to be spirituality. I was mourning Ibu's death at the time and the fact that I could feel this kind of deep body connection with her through the dance, was a great comfort and relief. I realised that this process had been going on for a long time and was part of the process of learning the dance, but that I hadn't been consciously aware of it until then. I knew that it wasn’t only Ibu, but all my previous dance teachers and people of importance in my life, whom I remembered in this embodied way. They literally became a part of my body and thus part of my identity, which is continually transforming to accommodate new encounters with people. This experience made me reflect on how disconnected we generally are in the West from our bodies. All those years of Descartes, rational enlightenment, and the Cartesian Split have left most of us walking, disconnected, rational brains. This modern metropolitan condition goes some way towards explaining the overriding sense of alienation and disconnection many feel and points in the direction of our desires for and fantasies about the exotic, natural, wild, savage Other. The idea of a deep mind/body connection, of course, is not a new one, and is the expressed goal of many other performance, movement, meditation, and theatre training techniques.

In retelling this experience I am hoping to get to the heart of what I mean by dancing the 'contact zone'. In our engagement I have physically and mentally tried on Ibu's dance and world for size and she has tried on mine. This dance does not eradicate the discrepancies of our histories, access to power, privilege, and knowledge. On the contrary, it incorporates them. By sharing one space, engaging in a dance or a conversation or whatever the form of interaction may be, we become 'real' to one another without having to become the same. Of course Ibu was not learning contemporary performance from me; why would she at the age of 75? She did, however, listen to me telling her what I do with influences from her dance in Australia, and she saw the pictures, listened to my feelings, fears and hopes about my work, family, 
friends and life. She watched me dance her dances, observed my strengths and weaknesses, saw me living with her family, came to live with me in my house in Yogyakarta, met my friends, and tried my food (she didn’t like it much). In other words, she also embodied me, the 'western Other' so that I, too, became 'real', a part of who she was. This becoming 'real' is available if we allow the Other in and give our-Otherselves in return. Perhaps the embodiment I am speaking of here is a form of cannibalism, a more positive kind that serves to discursively negate the colonial trope of savage uncivilised cannibal imposed by the west on the Other. ${ }^{18}$

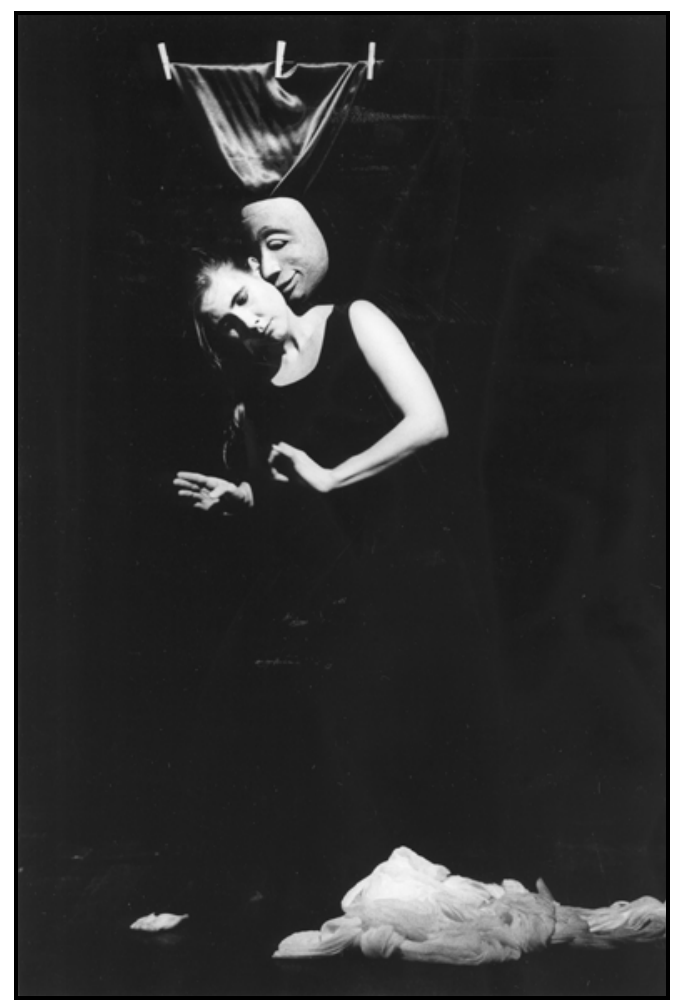

Me dancing in On-Lined, a contemporary performance, drawing on traditional Indonesian dance and mask, Performance Space, September 1995

\footnotetext{
${ }^{18}$ This kind of semiotic reversal of the cannibal trope was a strategy employed by the Brazilian cultural discourse of cannibalism (anthropophagy) which emerged in the 1920s to show that 'Primitivism should no longer be understood as a stage to be overcome, but instead as a valuable instrument for redeeming modern society from the excesses of capitalism' (Bellei 1998, 102). The ideas surrounding this discourse as summarised by Bellei from writings published in the journal Revista de Antropofogia published between May 1928 to August 1929 was the notion of 'the stomach without ideas, ready to devour everything' which was 'a metaphor for the cosmopolitan enterprise of absorbing both foreign and native cultures as the means to construe a hybrid and unique Brazilian identity' (Bellei 1998, 91).
} 
One of the important dynamics of my relationship with Ibu Sawitri, and one I feel I must emphasise here, is that our teacher/student relationship was based on a shared commitment and respect for the discipline of dance, in particular Ibu's style of Topeng Purwakencana. Even though I was paying for tuition, and the money was sorely needed, it is important to remember that there were definite rules associated with this student/teacher contract. Loyalty to Ibu and her dance was of utmost importance. I knew of one paying student Ibu had refused to continue teaching because the person in question had gone to ask some research questions to other mask dancers in the region about Ibu's past, without consulting her first. Considering the history of rivalry among different mask dancing troupes, this was a clear breach of trust. Even though this student was paying to learn dance and conduct research, Ibu refused to continue teaching her and was visibly hurt by the student's actions. I have no doubt that had I in some way undermined Ibu's authority as teacher or disrespected her reputation and dance, my fate would have been no different, regardless of my tuition fees. Ibu was a force to be reckoned with.

\section{Re-citing Ibu}

The pink 'pièce de resistance', 1980s-style, frilly vinyl sofa in the front room, which had not long before replaced the old Javanese teak bench, sold to an antique dealer for peanuts and no doubt resold to the west for a small fortune as an 'ancient Javanese love bench' or some such exotic title; the outside tiled and roofed dance floor; the small laminated chip wood table and rickety chairs in the middle of the house; or the front steps to the side of the main entrance to the house facing the pendopo: these were the usual places Ibu, her family and I would nongkrong and chat. In between dance lessons, which would usually be conducted for three hours in the morning and two hours in the afternoon, there was not an awful lot to do other than chat and ngemil. The local woman selling all manner of multicoloured sweet and savoury snacks, which she carried on her back from door to door, would miraculously appear with her delicacies just when we had settled down to talk. Our conversations included first and foremost copious amounts of village gossip, family dramas, personal worries and concerns. Husbands, boyfriends and the perfect match were an all-time favourite topic of conversation. Ibu, 
having been married six times, was of course an expert and an astute judge of character. On a more serious note discussions revolved around political developments like the then recent downfall of President Soeharto and the subsequent economic crisis, village wars and looting of local Chinese shops. But most of all when talking with Ibu we swapped memories of funny stories, and did lots and lots of talking up the past.

Sometimes I wanted to capture some of the stories she told me on film to include in the documentary I was then still trying to make. Periodically I would ask her if she would mind if we did an interview. She never objected and often told me that she was hoping that with the stories I was recording I would one day write a book about her life. Ibu was herself illiterate, and her older brother Punjul was the only one of the nine siblings who received a primary school education at the village volksschool (colonial-era elementary school). I always found doing the interviews very stressful. Peter had certain cinematographic considerations of light and aesthetics that he insisted on, so by the time we had asked Ibu to sit in the designated spot, fumbled with all the cables and got the microphones set up, I felt thoroughly uncomfortable. Ibu was amazingly good at dealing with all the fiddling about. She would have a cigarette while she waited for us and would just get on with yelling out instructions to her family about things needing to be done. I would start with a list of questions that I had formulated during the week based on things we had chatted about. In answer to my first question, Ibu would launch into an answer that very quickly veered off the topic because we had already spoken at length about it during the week. She would refer to shared knowledge, which of course when you are documenting something, doesn't work. I would try various different methods to elicit the information I was looking for, but never successfully. In the end I gave up trying, and I had to accept that I was not in control and would only ask questions relating to whatever she was talking about at the time. Peter found this process excruciating because the interview would last for hours and fill up tape after tape with seemingly directionless information. In retrospect however, I'm pleased that I stopped trying to steer the interviews because I am left with a record that is more openended. I have learned many new things about Ibu and myself from what she talked about, the questions for which I would at that time not have had the insight and 
understanding to ask.

During my five-month research period in the Dutch film archives, seeing shot after shot of beautiful dancing girls, in the palaces, in the villages, and on the streets, I often remembered with some embarrassment my own motivations in documenting Ibu's dance and life. My complicity with these colonial cameramen was uncomfortably present as I watched the archival footage. I would wonder if Ibu had ever been filmed when she was dancing as a young woman. It struck me then that Ibu as an old woman was the voice of these nameless, silent dancers of the archives. This thought grew into the realisation of the Ibu Camera box in Troppo Obscura. I wanted Ibu, who could have been any one of those village dancers I saw in the archives, some of whom I recast in the installation, to have a presence. I had listened to her voice over the eight years of studying and living with her. I knew that there was a very different story attached to this archival image of traditionele Javaanse danseressen and the way it was read and retold in the West. I wanted that story to be heard in the West as I had been told and therein, as Spivak reminds me, lies my dilemma.

\section{Reference list}

Bellei, S.L.P. 1998, Cannibalism and the New World, Cambridge University Press, Cambridge.

Chambers, I. 1996, 'Signs of Silence, Lines of Listening', in I. Chambers and L. Curti (eds), The Post-Colonial Question: Common Skies, Divided Horizons, Routledge, London, New York, 47-65.

Foley, K. 1985, 'The Dancer and the Danced: Trance Dance and Traditional Performance in West Java', Asian Theatre Journal, vol. 2, 128-149.

Fusco, C. 2001, The Bodies That Were Not Ours and Other Writings, Routledge, London and New York.

Foulcher, K. 1986, Social Commitment in Literature and the Arts: the Indonesian 'Institute of People's Culture', 1950-1965, Centre of Southeast Asian Studies Monash University, Clayton, Vic.

Geertz, C. 1976, The Religion of Java, University of Chicago Press, Chicago.

Hage, G. 2003, 'The Anatomy of Anti-Arab Racism,' The Australian Financial Review, 15 August, 9.

Holt, C. 1967, Art in Indonesia: Continuities and Change, Cornell University Press, Ithaca, NY.

Masunah, J. 2000, Sawitri Penari Topeng Losari, Tarawang, Yogyakarta. 
Pioquinto, C.E. 1995, Dangdut: Indonesian Popular Music: Gender and Performance, Unpublished PhD Thesis, University of Sydney.

Pratt, M.L. 1992, Imperial Eyes: Travel Writing and Transculturation, Routledge, London and New York.

Ricklefs, M.C. 2001, A History of Modern Indonesia Since c.1200, 3rd edn, Palgrave, Basingstoke.

Said, E. 1996, 'From Orientalism', in P. Mongia (ed.), Contemporary Post Colonial Theory, Arnold, New York.

Sawitri 1993, Interview with the author, Losari/Cirebon (Indonesia).

Sawitri 1996, Interview with the author, Losari/Cirebon (Indonesia).

Sawitri 1998, Interview with the author, Losari/Cirebon (Indonesia).

Sawitri 1999, Interview with the author, Losari/Cirebon (Indonesia).

Sawitri and Gamelan players 1996, Interview with the author, Losari/Cirebon (Indonesia).

Schechner, R. 1991, 'Intercultural Themes', in B. Marranca and G. Dasgupta (eds), Interculturalism and Performance, PAJ Publications, New York.

Sears, L.J. 1996, Fantasizing the Feminine in Indonesia, Duke University Press, Durham and London.

Sen, K. 1994, Indonesian Cinema: Framing the New Order, Zed Books, London.

Sen, K. and Hill, D.T. 2000, Media, Culture and Politics in Indonesia, Oxford University Press, Melbourne.

Spivak, G. 1988, 'Can the Subaltern Speak?' in G. Nelson and L. Grossberg (eds), Marxism and the Interpretation of Culture, MacMillan, London, 271-313.

Suanda, E. 1983, Topeng Cirebon: In its Social Context, Wesleyan University Press, Middletown, CT.

Suanda, E. 1988, 'Dancing the Cirebonese Topeng', Journal of the American Gamelan Institute, vol. 3, no. 3, 7-15. 